\title{
EDITORIAL
}

Versão original

DOI: http://dx.doi.org/10.1590/So034-759020200601

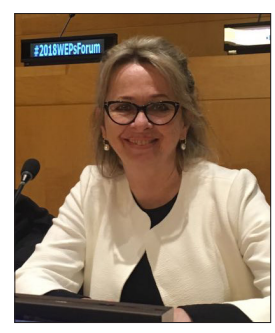

MARIA JOSÉ TONELLI Editora-chefe

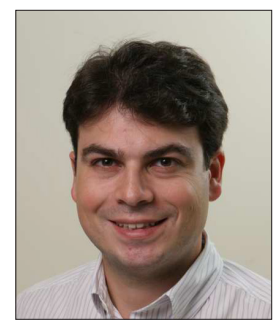

FELIPE ZAMBALDI Editor-adjunto

\section{PESQUISA E DISSEMINAÇÃO DE CONHECIMENTO NA PANDEMIA}

Nesta edição, apresentamos os artigos selecionados para a chamada de trabalho "Impactos da Covid-19 nas organizações”. Ainda que as estratégias de pesquisa em Administração de Empresas durante a pandemia precisaram ser revistas, uma vez que, muitas das investigações na área são conduzidas in loco nas organizações, o número de submissões para essa chamada de trabalho mostrou a pesquisa viva, pulsante, no meio da pandemia. As organizações foram profundamente impactadas, e, nos próximos anos, vão crescer as pesquisas sobre novos formatos organizacionais, sobre saúde mental nas organizações, sobre logística e operações, sobre marketing de consumo, e esperamos que sejam novas formas para o bem comum. 0 texto dos editores convidados, "Impactos da Covid-19 nas organizações", apresenta os principais temas que surgiram nessa chamada especial.

Quando se trata da produção científica durante o período pandêmico, porém, temos algumas questões que precisam ser debatidas. Em primeiro lugar, se, de um lado, a pandemia trouxe a necessidade de pesquisas urgentes sobre uma nova realidade que pede respostas rápidas sobre questões vitais, de outro, afetou as publicações acadêmicas, uma vez que aumentou a preocupação com o processo de revisão por pares, que passaram a trabalhar mais rapidamente, acarretando a possibilidade de maior número de erros e, consequentemente, de fraudes, como apresenta Fabricio Marques, na Revista Pesquisa FAPESP, em agosto de 2020. Nesse texto, é feito o alerta para a necessidade de preservação da qualidade da pesquisa, já que nem sempre os artigos publicados trazem contribuições que mantêm a integridade da pesquisa, como aponta Marques (2020), a partir de várias pesquisas e medidas adotadas internacionalmente.

Mas não apenas as pesquisas ligadas diretamente à Covid-19 sofreram durante a pandemia. Os processos de avaliação e publicação de artigos também tiveram que ser reajustados, pela dificuldade de vários pesquisadores e revisores com o home office; tais processos durante o período pandêmico deveriam ser considerados pelos órgãos avaliadores de produção editorial das revistas científicas.

Em segundo lugar, além das publicações, as formas de troca de conhecimento entre a comunidade científica também sofreram mudanças neste período. Passamos a apresentar trabalhos em congressos virtuais, com os aspectos positivos e outros nem tanto que esse tipo de interação permite. Sidinei Santos de Oliveira (2020) mostra que, com os congressos virtuais, diminuíram os custos com passagens e hospedagem, assim foi possível contar com a participação de um grande número de participantes, com abrangência mundial. A falta de experiência nessa modalidade trouxe imprevistos técnicos que poderão ser revistos para os próximos anos, já que a modalidade on-line deve continuar. Entretanto, definitivamente, 
esses encontros não permitem as conversações, as trocas de informações e possíveis novas redes de pesquisa que acontecem nos cafés, de modo informal. As interações nas conferências on-line precisam ser programadas e pedem etiquetas "para ficar bem no vídeo", como discute Oliveira (2020). Os pesquisadores precisam oferecer, além de suas pesquisas, a iluminação adequada, uma roteirização das apresentações e um controle de tempo estrito dos programas midiáticos. Nada fácil para quem se preparou ao longo dos anos para ser pesquisador, e não artista de cinema ou roteirista de programas de TV.

Tais aspectos, em conjunto com os recursos aplicados em pesquisa e a definição dos projetos que devem ser incentivados, precisam sofrer modificações nos próximos anos. É necessário ficar atento para não jogar fora o bebê com a água do banho. Sem dúvida, avanços são necessários na pesquisa, em especial nos temas atrelados aos Objetivos de Desenvolvimento Sustentável da ONU. Mas, como sempre, o progresso da ciência pede a democracia como princípio.

Falando de futuro, no próximo ano, a RAE completa 60 anos, e estamos preparando uma edição especial para celebrar o aniversário do periódico mais longevo na área de Administração de Empresas, quando consideramos suas seis décadas ininterruptas de publicação. Trata-se de um marco na história das publicações acadêmico-científicas no País. Para as comemorações dos 60 anos, teremos várias novidades a serem apresentadas ao longo de 2021, que incluem, para começar, já na próxima edição, a publicação dos artigos em fluxo contínuo.

Desejamos a todas e todos um feliz 2021, com respeito à pesquisa e com saúde!

Boa leitura!

Maria José Tonelli ${ }^{1}$ | ORCID: 0000-0002-6585-1493

Felipe Zambaldi ${ }^{1}$ | ORCID: 0000-0002-5378-6444

${ }^{1}$ Fundação Getulio Vargas, Escola de Administração de Empresas de São Paulo, São Paulo, SP, Brasil

\section{REFERÊNCIAS}

Marques, F. (2020, agosto). Integridade em meio à emergência sanitária. Revista Pesquisa FAPESP, ano 21(294), seção Boas Práticas, 8-9.

Oliveira, S. S. de. (2020, outubro). Encontros científicos on-line delineiam nova maneira de compartilhar conhecimento. Revista Pesquisa FAPESP, ano 21(296), 95-97. 